\title{
Fatigue Performance of Wet and Dry Pulverized Wood Flour Reinforced PP Composites
}

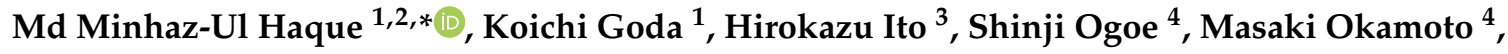 \\ Tomoyuki Ema ${ }^{4}$, Keiko Kagawa ${ }^{4}$ and Hidetaka Nogami ${ }^{5}$ \\ 1 Department of Mechanical Engineering, Yamaguchi University, 2-16-1 Tokiwadai, Ube, \\ Yamaguchi 755-8611, Japan; goda@yamaguchi-u.ac.jp \\ 2 Department of Applied Chemistry and Chemical Engineering, Islamic University, Kushtia-7003, Bangladesh \\ 3 Cellulose Materials Group, National Institute of Advanced Industrial Science and Technology, \\ 3-11-32 Kagamiyama, Higashihiroshima, Hiroshima 739-0046, Japan; itou.hirokazu@aist.go.jp \\ 4 Technology Development Center, TOCLAS Co., 1370 Nishiyama-cho, Nishi-ku, Hamamatsu, \\ Shizuoka 432-8001, Japan; shinji_ogoe@toclas.co.jp (S.O.); masaki_okamoto@toclas.co.jp (M.O.); \\ tomoyuki_ema@toclas.co.jp (T.E.); keiko_kagawa@toclas.co.jp (K.K.) \\ 5 Okayama Prefectural Research Institute for Forest and Forest Products, 1884-2 Katsuyama, Maniwa, \\ Okayama 717-0013, Japan; hidetaka_nogami@pref.okayama.lg.jp \\ * Correspondence: minhaz1978@gmail.com; Tel.: +81-506-865-0354
}

Received: 30 November 2018; Accepted: 30 January 2019; Published: 14 February 2019

\begin{abstract}
In this paper, we exclusively studied the effects of dry and wet pulverization of different wood flours on the fatigue performance of polypropylene (PP)/wood flour (WF) composites. Wood flours obtained from cypress and Scots pine trees were pulverized in both dry and wet conditions at two different mill-plate gaps, $200 \mu \mathrm{m}$ and $350 \mu \mathrm{m}$, and were used as reinforcement in PP matrices. Master batches of PP with different types of pulverized WF were compounded before processing in an extruder. The PP/WF composites of initial WF were also prepared for comparison. The prepared composites were analyzed by tensile and fatigue tests. It was found that the tensile properties of wood/polypropylene composites were affected by the pulverization of WF. Fatigue test results displayed that wet pulverization of short cypress flour had a negative effect on the fatigue life of PP/WF composites, while wet pulverization of long cypress flour and pine flour had a positive effect on the fatigue life of PP/WF composites.
\end{abstract}

Keywords: wood-plastic composite (WPC); fatigue behavior; wood flour; polypropylene

\section{Introduction}

The polypropylene (PP)/wood flour (WF) composite, a kind of wood-plastic composite (WPC) material, is an engineering material obtained by a reinforcement of polypropylene matrix using wood flour. The application of this material in different sectors, such as automotive industries, office appliances, housewares, furniture, etc. [1-3], is increasing day by day because it has several advantages, of which the most important is its being an eco-friendly material. It has also other advantages, such as recyclability (i.e., it can be made from recycled wood and recycled polypropylene), availability, cost-effectiveness, etc. The availability of wood flour, its low cost, and its free flowing nature compared with natural fibers has also drawn the attraction of WPC companies and users [4]. Hence, the application of and demand for wood-plastic composites (WPCs) is increasing day by day. In parallel, research is in progress both in academic institutions and in industries for further development of the performance and properties of these composite materials. A number of researchers have attempted to improve the fire resistance properties of WPCs [5-7], while others have attempted to find a new application of these materials [8]. Research to improve the moisture resistance of 
WPCs [9-13] has also been done. In addition, studies to develop the interfacial strength of PP and WF, i.e., strong bonding between PP and WF [1,14-27], have also been reported. The development in the mechanical properties of wood-plastic composite can also be one step ahead by pulverization of the wood flour. Usually, commercial wood flour which is used as a filler in thermoplastic resin, is a mixture of different particle sizes and has a low aspect ratio [28]. Pulverization of wood flour can bring changes in wood flour particle aspect ratio, the ratio of the length to width of particles, which has a large effect on the mechanical properties of PP/WF composites. It has also been reported that the mechanical properties of PP/WF composites were largely affected by the wood flour content as well as the aspect ratio of the WF [28-30]. Although it was reported that smaller particles provided better properties of composites, characterization of the properties of commercial wood-plastic composites on the basis of wood flour particle sizes was not simple [31].

Recently, we and very few other researchers have been trying to further develop the mechanical properties of WPCs, approaching the problem with pulverization of WF. Zhihai et al. [32] reported that the aspect ratio of WF was increased by pulverization, and the resulting PP/WF composites exhibited an improved mechanical performance. However, Makise et al. [33] observed that excessive pulverization of WF in dry conditions had a negative effect on the mechanical properties of PP/WF composites. In our previous study, it was found that wet pulverized WF reinforced PP composites displayed a higher melt viscosity than that of the initial and dry pulverized wood flour reinforced PP composites [34]. The higher melt viscosity indicated more interfacial interaction between the PP matrix and the wood flour. It was also found that the tensile strength of pulverized WF composites was higher than that of the non-pulverized WF composites [35]. Hence, pulverization of wood flour with water may have a positive effect on the mechanical properties of PP/WF composites. Moreover, pulverization of WF with water, a simple mechanical treatment, is a nonhazardous approach compared with any other existing treatment of wood flour.

Since the tensile strength of WPC was improved by pulverization of WF, it could be expected that the process would also affect the fatigue life of WPC. The study of fatigue behavior of composites is particularly important if wood-plastic composites are to be subjected to use in long-term load bearing applications. The materials' deformation mechanisms under short-term and long-term mechanical loading are not always the same; therefore, it is necessary to study their fatigue life. Tensile tests alone may not be enough to make a prediction of their long-term load bearing application [36]. Though flexural fatigue analysis of WPCs has been reported in the literature [37], tensile fatigue test analysis of PP/WF composites has not been done yet. Reliability data of WPCs in long-term load bearing application can be obtained by a detailed fatigue analysis of the WPC. Therefore, in the present study, attention was given to investigating if there is any effect of the pulverization of wood flour on the fatigue life of PP/WF composites. If so, then how does the pulverization of wood flour affect the fatigue life of wood composites? Thus, investigation of the effect of pulverization of wood flour on the fatigue life of WPCs is the main focus of this study.

The specific objective of this study was to investigate the effect of dry and wet pulverization of three different commercial wood flours, namely, short-size cypress flour, long-size cypress flour, and Scots pine flour, on the fatigue life of PP/WF composites. In our previous studies [34], a mechanism of pulverization of wood flour was reported. In the case of dry pulverization of wood flour, the particle size was reduced by splitting either the longer particles along their width or short particles along their length, whereas if pulverization of wood flour occurred in wet conditions, then not only was the particle size reduced, but a fibrillation was also created on the wood flour particle surfaces. The presence of fibrils on the wood flour particle surfaces indicated more interfacial interaction between the PP and the wood flour. It was assumed that the presence of fibrils on the surfaces of wet pulverized wood flour would improve the crack resistance properties of wood flour. Further, fibrils could assist formation of inter-particle networks in matrices. Thus, assuming more interfacial interaction and improved crack arresting properties of wet pulverized WF, a higher fatigue life of wet pulverized wood flour reinforced polypropylene composites was expected. 


\section{Materials and Methods}

\subsection{Materials}

Three kinds of raw materials, namely, wood flour (WF), polypropylene, and maleic anhydride grafted polypropylene were used to fabricate the composites. Different types of wood flours, such as short-size cypress flour $\left(\mathrm{CWF}_{\mathrm{S}}\right)$, long-size cypress flour $\left(\mathrm{CWF}_{\mathrm{L}}\right)$, and Scots pine flour $(\mathrm{PWF})$ were received from Maniwa City. According to the analyzer, described later, the average wood flour particle sizes of $\mathrm{CWF}_{\mathrm{S}}, \mathrm{CWF}_{\mathrm{L}}$, and PWF were 165.0, 379.2, and $265.0 \mu \mathrm{m}$, respectively.

Polypropylene (PP) pellet, trade name PPJ107G, melt flow index $30 \mathrm{~g} / 10 \mathrm{~min}$ at $230{ }^{\circ} \mathrm{C} / 2.16 \mathrm{~kg}$, density $0.9 \mathrm{~g} / \mathrm{cm}^{3}$, melting point $150{ }^{\circ} \mathrm{C}$ was received from Prime Polymer Co., Ltd., Tokyo, Japan.

Maleic anhydride grafted polypropylene (MAPP) powder with $2 \mathrm{wt}$ \% maleic anhydride (MA) content was supplied from Kayaku Akzo Co., Ltd., Tokyo, Japan.

\subsection{Pulverization of Wood Flour}

Different types of initial wood flours, $\mathrm{CWF}_{\mathrm{S}}, \mathrm{CWF}_{\mathrm{L}}$, and $\mathrm{PWF}$, were individually pulverized in both dry and wet conditions at two different mill-plate gaps, 200 and $350 \mu \mathrm{m}$. Before pulverization, each type of initial wood flour was agitated in a canna refuse (Mulder scrap) by an impact pulverizer and Makino type crusher DD-3. For pulverization of each type of initial wood flour, its agitated slurry was passed through a disc milling Masscolloider MKZA 10-15 J, Whetstone, MKE 10-80, Japan. The mill-plate size was $24 \mathrm{~cm}$, and the rotational speed of the plate was $1800 \mathrm{rpm}$. For each load, $50 \mathrm{~g}$ wood flour was passed 5 times through the pulverizer. In the case of wet pulverization, a slurry with solid content $5 \mathrm{wt}$. \% was first prepared by agitation.

After pulverization, the solid wood flour was separated by a centrifuge machine (Micro Refrigerated Centrifuge 3700, Kubota Manufacturing Co., Tokyo, Japan). t-Butyl alcohol (2-methyl- 2-propanol, Wako Pure Chemical Industries Ltd., Osaka, Japan) was used to dehydrate the pulverized wood flour. Finally, the pulverized wood flour was dried through the centrifugation and dehydration steps, followed by freeze drying. Five categories of wood flour were obtained after pulverization of each type of initial flour, as reported in Table 1.

Table 1. List of different types of wood flours and composite samples with their code.

\begin{tabular}{|c|c|c|c|c|c|}
\hline \multirow{2}{*}{$\begin{array}{l}\text { Sample Abbreviation } \\
\text { for Wood Flour }\end{array}$} & \multirow{2}{*}{ Sources (tree) } & \multicolumn{2}{|c|}{ Pulverization Conditions } & \multirow{2}{*}{$\begin{array}{c}\text { Average Wood } \\
\text { Particle Size }(\mu \mathrm{m})\end{array}$} & \multirow{2}{*}{$\begin{array}{c}\text { Average Wood } \\
\text { Particle Aspect Ratio }\end{array}$} \\
\hline & & Mill-plate Gap ( $\mu \mathrm{m})$ & Water & & \\
\hline $\mathrm{CWF}_{\mathrm{S}} \mathrm{OO}$ & \multirow{5}{*}{ Cypress } & - & - & 165.0 & 5.9 \\
\hline $\mathrm{CWF}_{\mathrm{S}} 200$ & & 200 & \multirow{2}{*}{ No } & 165.4 & - \\
\hline $\mathrm{CWF}_{\mathrm{S}} 350$ & & 350 & & 161.7 & - \\
\hline $\mathrm{CWF}_{\mathrm{S}} 200 \mathrm{w}$ & & 200 & \multirow{2}{*}{ Yes } & 135.0 & 3.9 \\
\hline $\mathrm{CWF}_{\mathrm{S}} 350 \mathrm{w}$ & & 350 & & 167.0 & - \\
\hline $\mathrm{CWF}_{\mathrm{L}} 00$ & \multirow{5}{*}{ Cypress } & - & - & 379.2 & 2.3 \\
\hline $\mathrm{CWF}_{\mathrm{L}} 200$ & & 200 & \multirow{2}{*}{ No } & 313.9 & - \\
\hline $\mathrm{CWF}_{\mathrm{L}} 350$ & & 350 & & 323.1 & - \\
\hline $\mathrm{CWF}_{\mathrm{L}} 200 \mathrm{w}$ & & 200 & \multirow{2}{*}{ Yes } & 245.9 & 3.3 \\
\hline $\mathrm{CWF}_{\mathrm{L}} 350 \mathrm{w}$ & & 350 & & 304.7 & - \\
\hline PWF00 & \multirow{5}{*}{ Scots pine } & - & - & 265.7 & 4.2 \\
\hline PWF200 & & 200 & \multirow{2}{*}{ No } & 201.2 & - \\
\hline PWF350 & & 350 & & 213.9 & - \\
\hline PWF200w & & 200 & \multirow[b]{2}{*}{ Yes } & 168.4 & 4.3 \\
\hline PWF350w & & 350 & & 198.7 & - \\
\hline
\end{tabular}

* Subscripts $\mathrm{S}$ and L indicate short and long particles, respectively.

\subsection{Processing of Composite}

The PP/WF composites of initial wood flour and pulverized wood flour were prepared in two steps. In the first step, master batches of PP and MAPP with $70 \mathrm{wt}$. \% wood flour were prepared by a 
compounding machine, Super Mixer SMV-20. The compounding process was accomplished at $190{ }^{\circ} \mathrm{C}$ and stirring blade rotating speed of $2000 \mathrm{rpm}$.

In the second step, the ground master batches were processed in a twin-screw extruder (AS30, Nakatani Machinery Co., Ltd., Tokyo, Japan) by the addition of required amount of neat PP to make the components' composition wt. \% in each final composite, 74PP/1MAPP/25WF. During processing of the composites, the temperature at the different zones in the extruder were maintained as following: (1) $165^{\circ} \mathrm{C}$, (2) $200^{\circ} \mathrm{C}$, (3) $215^{\circ} \mathrm{C}$, (4) $200^{\circ} \mathrm{C}$, (5) $190^{\circ} \mathrm{C}$, and (6) $190{ }^{\circ} \mathrm{C}$. The screw speed of the extruder was $85 \mathrm{rpm}$, and the total throughput was $9-12 \mathrm{Kg} / \mathrm{h}$. The processed composites based on different wood flour were coded as reported in Table 1.

\subsection{Characterization Techniques}

The average particle size and size distributions of different pulverized wood flours were determined by a laser diffraction particle size distribution analyzer (Partica LA-950V2, Horiba, Ltd., Kyoto, Japan). The analyzer was connected with two different light sources, a $650 \mathrm{~nm}$ red laser diode and a $405 \mathrm{~nm}$ blue emitting diode. Particle sizes, from $3 \mathrm{~mm}$ to $10 \mathrm{~nm}$, were measured accurately by applying Mie scattering theory. The average particle size of a sample indicated the average value obtained from the particle size distribution. The average particle sizes of individual wood flours obtained from the particle size distribution are reported in Table 1.

Scanning electronic microscopic (SEM) analysis of different wood flours was done by a field emission scanning electron microscope (Hitachi High-tech S-4800, Hitachi, Tokyo, Japan) operating at $15 \mathrm{kV}$. Before analysis, the surfaces of wood flour particles were sputter coated with a layer of gold in an Edward Sputter Coater.

Tensile tests of dumbbell shaped specimens, obtained by injection molding, of the composites was carried out by a Material Testing Machine, EHF-F1, Shimadzu, Japan. A strain gauge (Kyowa strain gauge, KFGS-2N-120-C1-11, Osaka, Japan) of $2 \mathrm{~mm}$ with a gauge factor of $2.14 \pm 1.0 \%$ was inserted on the surface (at the middle point) of each specimen. The specimens were conditioned in a humidity control chamber at $25{ }^{\circ} \mathrm{C}$ and $40 \%$ relative humidity (RH) for 5 days. The conditioned specimens were tested using a load cell of $1 \mathrm{kN}$, gauge length of $18 \mathrm{~mm}$, and cross-head speed of $10 \mathrm{~mm} / \mathrm{min}$ at $25^{\circ} \mathrm{C}$ and $40 \%$ relative humidity. The average maximum strength of composite samples was calculated by performing the test on five specimens.

Fatigue tests of the composite specimens were carried out by the same instrument as used for the tensile test. The fatigue test of the composites was also conducted at conditions of $25^{\circ} \mathrm{C}$ and $40 \%$ $\mathrm{RH}$. The average maximum tensile strength value, obtained by tensile test, was used as a reference maximum stress level in estimation of the applied stress. The following test conditions were applied in fatigue test: tension-tension loading mode, stress ratio 0.1 , frequency $3.5 \mathrm{~Hz}$, and applied stress: $90,80,70,60$, and $55 \%$ level of ultimate tensile strength. At each load, at least two specimens of the composites were tested.

Crack propagation of the fatigue fractured specimens of the composites were examined with an optical microscope (Hirox Digital Microscope-KH-1300M, Hirox, Tokyo, Japan) equipped with a CCD camera. After fatigue test, the broken pieces of the specimens were put on a glass slide arranged as before breaking. The crack was investigated by focusing on the broken pieces, and photos were captured.

\section{Results and Discussion}

\subsection{Wood Particle Size Distribution}

The particle size distribution curves of different types of initial and pulverized wood flours in both dry and in wet conditions at mill-plate gaps 200 and $350 \mu \mathrm{m}$ are shown in Figure 1. The average particle sizes of different wood flours obtained from particle size distribution analysis are also reported in Table 1. Figure $1 \mathrm{a}-\mathrm{c}$ represents the particle size distribution curves of $\mathrm{CWF}_{\mathrm{S}}, \mathrm{CWF}_{\mathrm{L}}$, and $\mathrm{PWF}$, 
respectively. The reduction of particle size in the pulverized WF both in dry and in wet conditions compared with the initial WF particles is obvious in Figure $1 b, c$, whereas no reduction occurred in dry condition as shown in Figure 1a. In the particle size distribution curves, it was also noticed that, due to the wet pulverization of wood flour, at mill-plate gap $200 \mu \mathrm{m}$, the particle size was reduced significantly for every type of wood flour compared with the particle size of the dry pulverized wood flour. Thus, the particle size analysis indicated that the presence of water assisted to reduce the particle size of wood flour more efficiently. Perhaps water enhanced particle splitting by facilitating the breaking of inter fibrillar hydrogen bonds within the particle.
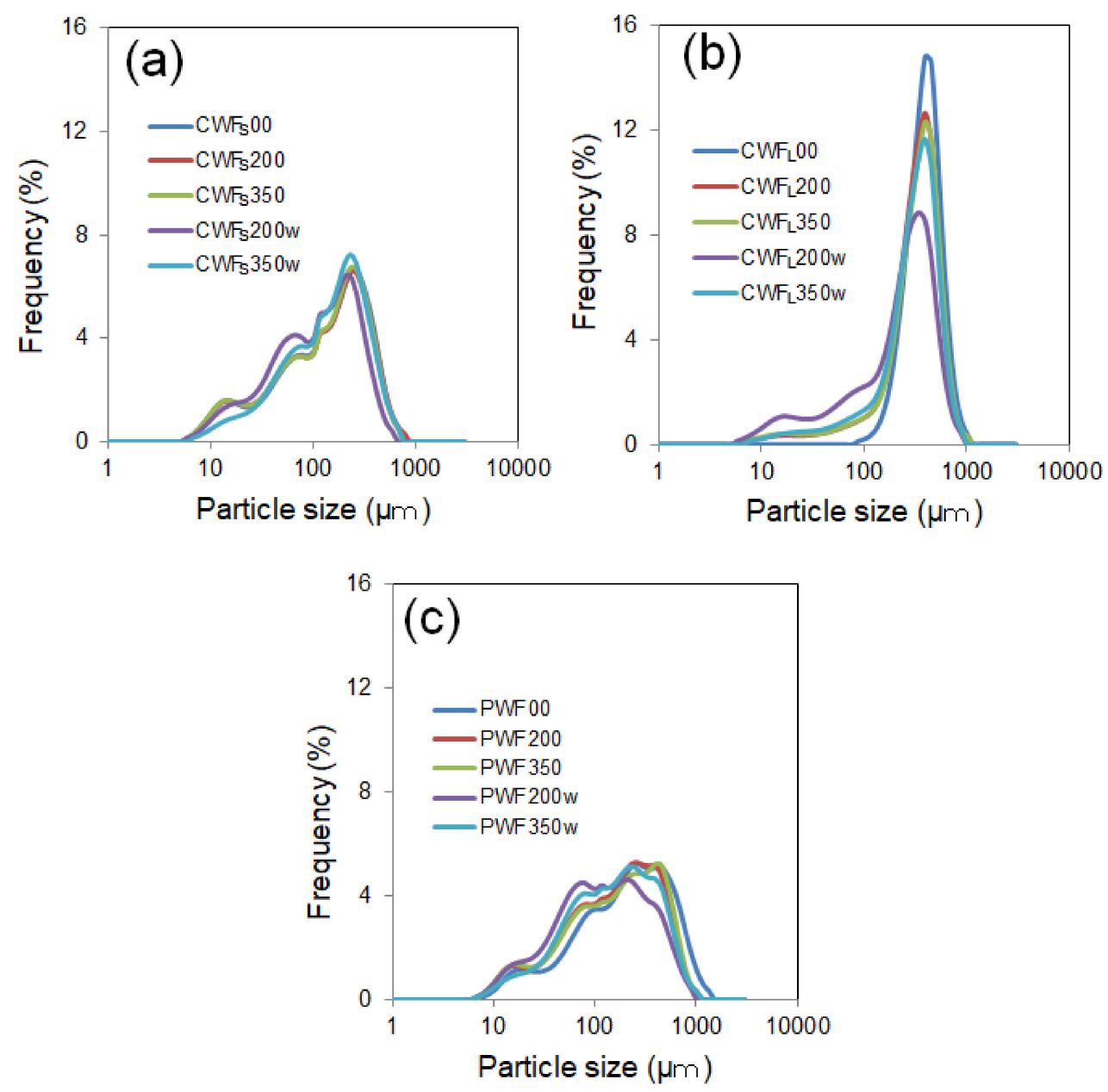

Figure 1. Wood particle size distribution curves of initial (00), dry pulverized at mill-plate gap $200 \mu \mathrm{m}$ (200), dry pulverized at mill-plate gap $350 \mu \mathrm{m}$ (350), wet pulverized at mill-plate gap $200 \mu \mathrm{m}(200 \mathrm{w})$, and wet pulverized at mill-plate gap $350 \mu \mathrm{m}(350 \mathrm{w})$ respectively, of (a) short cypress flour $\left(\mathrm{CWF}_{\mathrm{S}}\right)$, (b) long cypress flour $\left(\mathrm{CWF}_{\mathrm{L}}\right)$, and $(\mathrm{c})$ pine flour $(\mathrm{PWF})$.

\subsection{Wood Flour Morphology and Aspect Ratio}

Figure 2 represents the scanning electron micrographs of different types of WFs, (a) $\mathrm{CWF}_{\mathrm{S}} 00$, (b) $\mathrm{CWF}_{\mathrm{S}} 200 \mathrm{w}$, (c) $\mathrm{CWF}_{\mathrm{L}}$ 00, (d) $\mathrm{CWF}_{\mathrm{L}} 200 \mathrm{w}$, (e) PWF00, and (f) PWF200w. From these images, average WF particle aspect ratios (a.r) were calculated using an image processing software (ImageJ). The aspect ratio values are also reported in Table 1 . In Figure 2, the images $(a, c, e)$ at the left hand side are representative of the initial $\mathrm{WF}$, and the images $(\mathrm{b}, \mathrm{d}, \mathrm{f})$ at right hand side are representative of the wet pulverized WF at mill-plate gap $200 \mu \mathrm{m}$. In the SEM images of initial WFs (Figure 2a,c,e), it is seen that the WF particle aspect ratios of $\mathrm{CWF}_{\mathrm{S}} 00$ and PWF00 were notably higher than that of $\mathrm{CWF}_{\mathrm{L}} 00$. The reduction of WF particle size in wet pulverized WF compared with the initial WF particles can also be noticed in the SEM images of Figure 2. The particle size reduction was more obvious in the 
case of $\mathrm{CWF}_{\mathrm{L}}$. Observing the particle size and shape in the SEM images of Figure 2a,b, it is seen that the aspect ratio value of $\mathrm{CWF}_{S} 200 \mathrm{w}$ (a.r 3.9) was reduced compared with $\mathrm{CWF}_{S} 00$ (a.r 5.9). In the case of $\mathrm{CWF}_{\mathrm{L}}$, i.e., comparing the SEM images of Figure $2 \mathrm{c}, \mathrm{d}$, it can be easily estimated that the particle aspect ratio of $\mathrm{CWF}_{\mathrm{L}} 200 \mathrm{w}$ (a.r 3.3) was higher than that of $\mathrm{CWF}_{\mathrm{L}} 00$ (a.r 2.3).
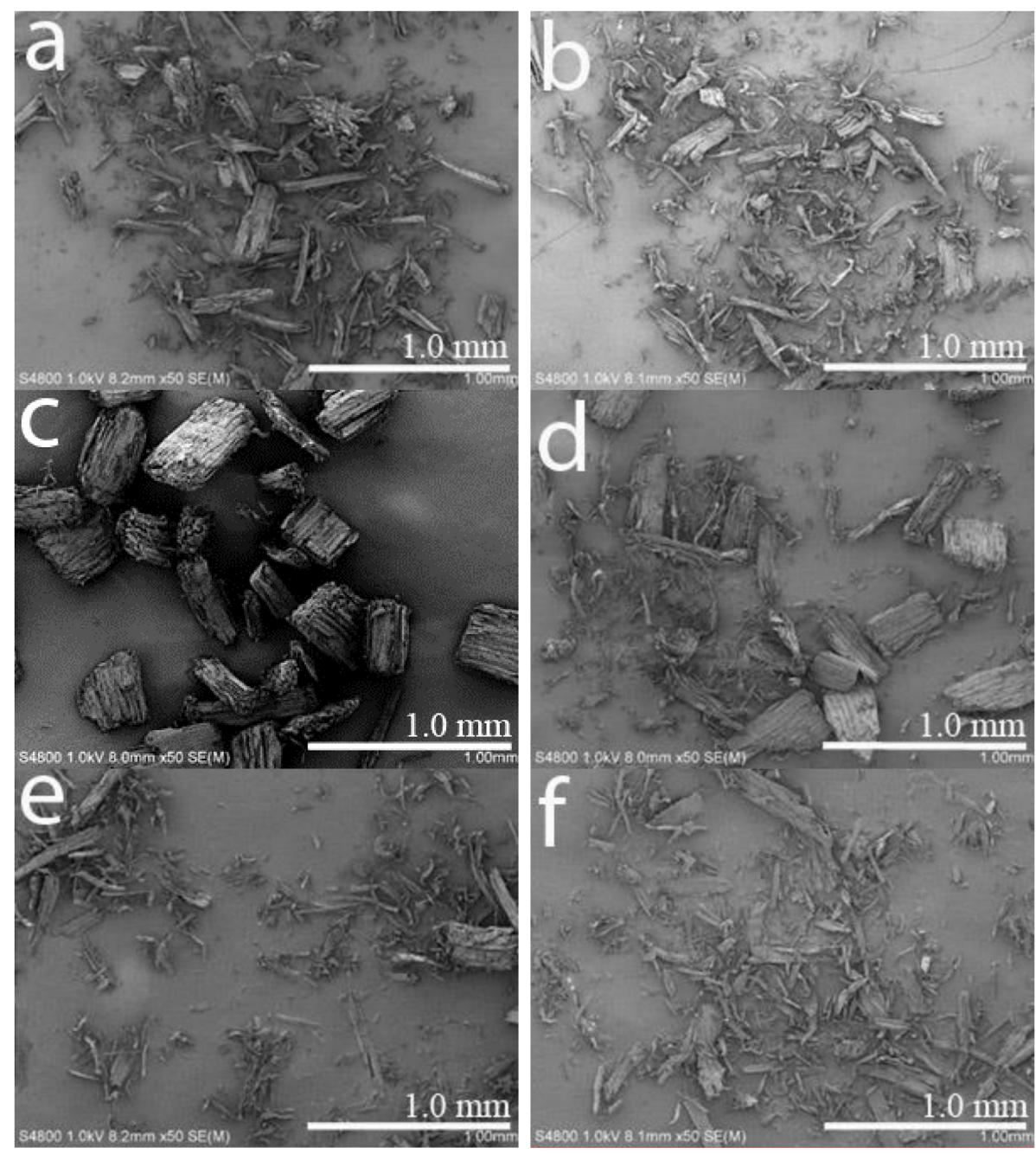

Figure 2. Scanning electron microscopic images of (a) $\mathrm{CWF}_{\mathrm{S}} 00$, (b) $\mathrm{CWF}_{\mathrm{S}} 200 \mathrm{w}$, (c) $\mathrm{CWF}_{\mathrm{L}} 00$, (d) $\mathrm{CWF}_{\mathrm{L}} 200 \mathrm{w}$, (e) PWF00, and (f) PWF200w.

\subsection{Tensile Properties of Composites}

Figure 3 shows the stress-strain curves of $\mathrm{CWF}_{\mathrm{S}} 00, \mathrm{CWF}_{\mathrm{S}} 200, \mathrm{CWF}_{\mathrm{S}} 350, \mathrm{CWF}_{\mathrm{S}} 200 \mathrm{w}$, and $\mathrm{CWF}_{\mathrm{S}} 350 \mathrm{w}$ composites. As reported in Table 2 and as shown in Figure 3, the tensile strength of both dry and wet pulverized $\mathrm{CWF}_{\mathrm{S}}$ composites were not improved, rather, were somewhat deteriorated compared with the $\mathrm{CWF}_{\mathrm{S}} 00$ composite. The tensile strength of polymer composites depends on particle aspect ratio, hence, the tensile test results indicated that particle aspect ratio was deteriorated after pulverization of $\mathrm{CWF}_{\mathrm{S}}$ [28]. Although it was predicted that wet pulverization of WF might improve the tensile strength of composites, neither dry nor wet pulverization of short-size cypress WF had a positive effect on the tensile strength of short-size cypress WF reinforced PP composites. Even the equipment parameter, mill-plate gap, did not show any significant difference in the tensile properties of these composites. Thus, the tensile test results indicated that the pulverization of $\mathrm{CWF}_{\mathrm{S}}$ was not an effective process for the composites. 


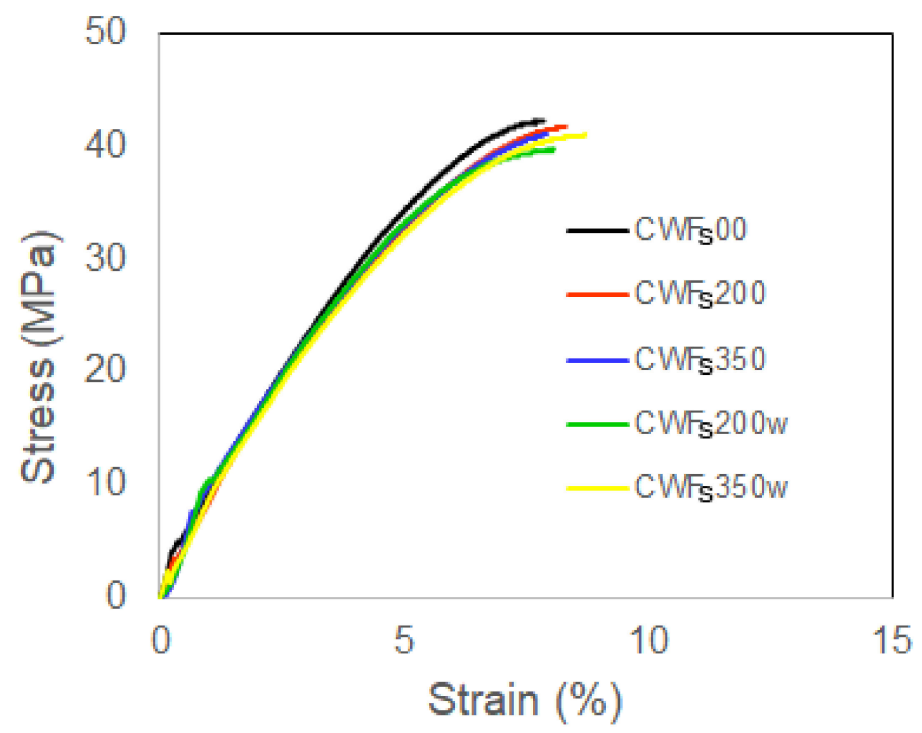

Figure 3. Stress-strain curves of $\mathrm{CWF}_{S}$ type composites: $\mathrm{CWF}_{S} 00, \mathrm{CWF}_{\mathrm{S}} 200, \mathrm{CWF}_{\mathrm{S}} 350, \mathrm{CWF}_{\mathrm{S}} 200 \mathrm{w}$, and $\mathrm{CWF}_{\mathrm{S}} 350 \mathrm{w}$.

Table 2. Tensile and fatigue strength of different types of WF filled PP composites.

\begin{tabular}{|c|c|c|c|}
\hline \multirow{2}{*}{ Wood Flour } & \multirow{2}{*}{ Tensile Strength (MPa) } & \multicolumn{2}{|c|}{ * Fatigue Strength (MPa) at Different Number of Cycle (N) } \\
\hline & & $10^{3}(\mathrm{~N})$ & $10^{6}(\mathrm{~N})$ \\
\hline $\mathrm{CWF}_{\mathrm{S}} \mathrm{O0}$ & $43.42 \pm 0.50$ & 37.3 & 26.1 \\
\hline $\mathrm{CWF}_{\mathrm{S}} 200$ & $42.89 \pm 0.43$ & 37.4 & 26.0 \\
\hline $\mathrm{CWF}_{\mathrm{S}} 350$ & $42.32 \pm 0.11$ & 37.0 & 26.0 \\
\hline $\mathrm{CWF}_{\mathrm{S}} 200 \mathrm{w}$ & $41.10 \pm 0.43$ & 36.5 & 25.1 \\
\hline $\mathrm{CWF}_{\mathrm{S}} 350 \mathrm{w}$ & $42.01 \pm 0.38$ & 36.4 & 25.7 \\
\hline $\mathrm{CWF}_{\mathrm{L}} \mathrm{O0}$ & $40.09 \pm 0.21$ & 34.8 & 24.3 \\
\hline $\mathrm{CWF}_{\mathrm{L}} 200$ & $40.14 \pm 0.36$ & 34.1 & 24.6 \\
\hline $\mathrm{CWF}_{\mathrm{L}} 350$ & $39.52 \pm 0.11$ & 34.0 & 23.9 \\
\hline $\mathrm{CWF}_{\mathrm{L}} 200 \mathrm{w}$ & $40.46 \pm 0.16$ & 35.7 & 24.8 \\
\hline $\mathrm{CWF}_{\mathrm{L}} 350 \mathrm{w}$ & $41.28 \pm 0.33$ & 35.4 & 24.9 \\
\hline PWF00 & $42.01 \pm 0.17$ & 36.0 & 24.2 \\
\hline PWF200 & $42.41 \pm 0.16$ & 36.7 & 25.5 \\
\hline PWF350 & $42.01 \pm 0.40$ & 36.6 & 25.2 \\
\hline PWF200w & $42.47 \pm 0.29$ & 36.6 & 25.6 \\
\hline PWF350w & $43.73 \pm 0.36$ & 35.9 & 25.0 \\
\hline
\end{tabular}

* Fatigue strengths were calculated from regression Equation (1).

Figure 4 shows the stress-strain curves of the $\mathrm{CWF}_{\mathrm{L}}$ composites. Although pulverization of $\mathrm{CWF}_{\mathrm{S}}$ exhibited a negative effect on the tensile strength of the composites, pulverization of $\mathrm{CWF}_{\mathrm{L}}$ exhibited a positive effect on the tensile strength. In particular, $\mathrm{CWF}_{\mathrm{L}} 200 \mathrm{w}$ and $\mathrm{CWF}_{\mathrm{L}} 350 \mathrm{w}$ composites displayed higher tensile strength compared with that of initial and dry pulverized $\mathrm{CWF}_{\mathrm{L}}$. This improvement in tensile strength of the composites can be attributed to the higher aspect ratio of wet pulverized $\mathrm{CWF}_{\mathrm{L}}$. Thus, the tensile test results indicated that the wet pulverization of $\mathrm{CWF}_{\mathrm{L}}$ was an effective process, as it improved the tensile strength. 


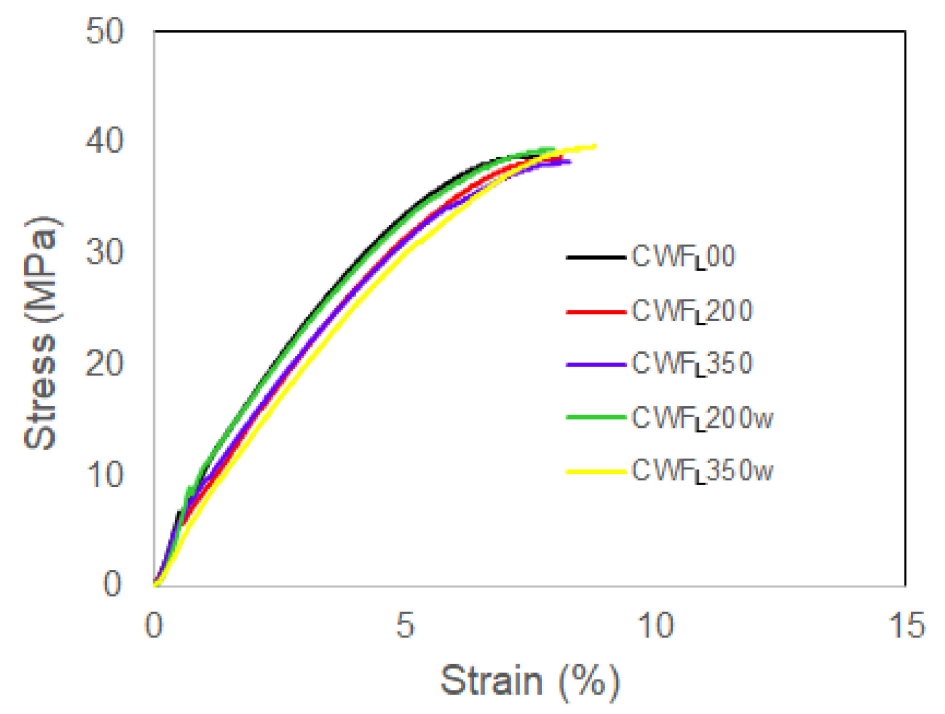

Figure 4. Stress-strain curves of $\mathrm{CWF}_{\mathrm{L}}$ type composites: $\mathrm{CWF}_{\mathrm{L}} 00, \mathrm{CWF}_{\mathrm{L}} 200, \mathrm{CWF}_{\mathrm{L}} 350, \mathrm{CWF}_{\mathrm{L}} 200 \mathrm{w}$, and $\mathrm{CWF}_{\mathrm{L}} 350 \mathrm{w}$.

Figure 5 shows the stress-strain curves of PWF composites. The tensile test results of PWF composites also supported the positive effect of the pulverization of PWF on the tensile strength of composites. It should be mentioned here, the particle size of initial PWF was $265.7 \mu \mathrm{m}$, which was between the initial particle size of $\mathrm{CWF}_{\mathrm{S}}(165 \mu \mathrm{m})$ and $\mathrm{CWF}_{\mathrm{L}}(379.2 \mu \mathrm{m})$. It seems the positive effect of WF pulverization depended on initial particle size of WF. However, the tensile strength of composites depended on aspect ratio, not particle size, of the WF [28]. Thus, from the tensile test analysis, it was concluded that if pulverization of WF improved the aspect ratio value of wood flour particles, then the pulverization of WF would be an effective process for the improvement of tensile strength of WPC.

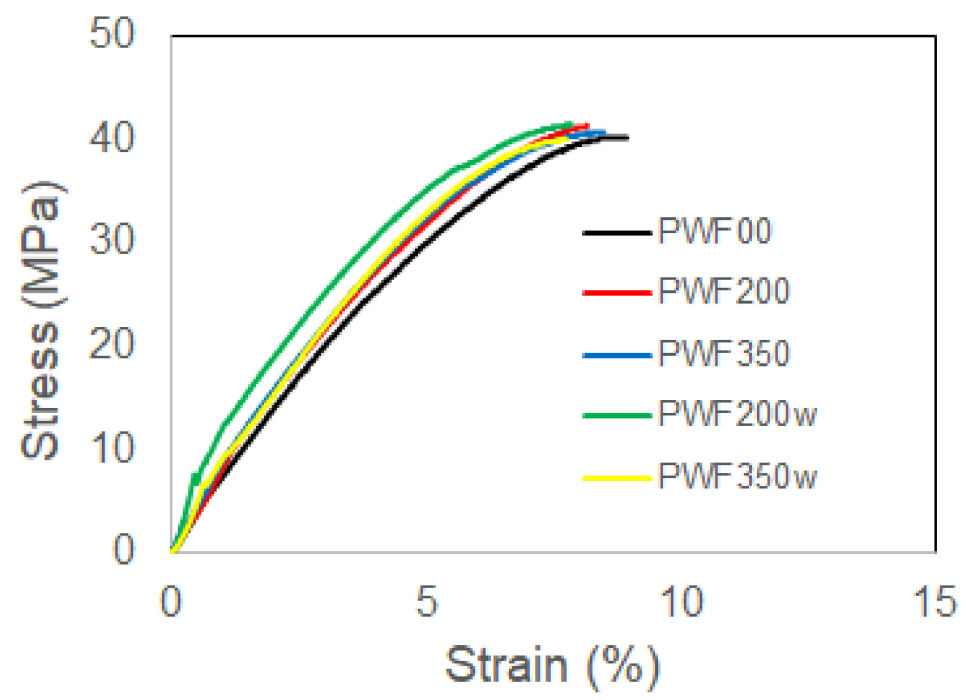

Figure 5. Stress-strain curves of PWF type composites: PWF00, PWF200, PWF350, PWF200w, and PWF350w.

\subsection{Fatigue Behavior of Composites}

Usually, composite material exhibits higher fatigue performance compared with its matrix material [38]. Hard filler particles can reduce the degree of matrix deformation in front of the crack tip that propagates in soft matrices [39]. In our previous study [40], it was also found that PP/WF composites exhibited improved fatigue life over that of PP matrix because of the delay of crack occurrence. Hence, the purpose of this study was to investigate the effects of different initial and 
pulverized wood flours on the fatigue life of PP/WF composites. To study the fatigue performances of the composites, maximum stress versus number of cycles to fracture (S-N) curves of initial and pulverized WF-reinforced PP/WF composites were plotted using the fatigue test data. Using the regression technique, the test data were then fitted in a logarithmic linear equation, as shown below:

$$
\sigma_{\max }=\mathrm{b} \cdot \log (\mathrm{N})+\mathrm{c}
$$

where $\sigma_{\max }$ is an applied maximum stress and $\mathrm{N}$ is a number of cycles to fracture. The values of $\mathrm{b}$ and $c$ are constant, and depend on the type of materials. For each and every composite material, the values of correlation coefficient and $\mathrm{R}^{2}$ were found to be about -0.83 and $>0.98$, respectively. The value of the correlation coefficient, -0.83 , indicated a strong downhill (negative) linear relationship. Fatigue strengths of the PP/WF composites at two different numbers of cycles were also calculated based on Equation (1), and the values are reported in Table 2.

Figure 6a represents S-N curves, and Figure $6 \mathrm{~b}$ represents the 50\% fatigue life (at $30 \mathrm{MPa}$ fatigue strength) column diagram of $\mathrm{CWF}_{\mathrm{S}}$ type composites. At constant fatigue strength ( $30 \mathrm{MPa}$ ), $50 \%$ fatigue lives were calculated based on Equation (1), and the column diagram shown in Figure $6 \mathrm{~b}$ was made. In Figure $6 \mathrm{~b}$, it can be noticed that $\mathrm{CWF}_{\mathrm{S}} 00, \mathrm{CWF}_{\mathrm{S}} 200$, and $\mathrm{CWF}_{\mathrm{S}} 350$ composites exhibited almost equal fatigue life. In Figure 6b, it is also seen that CWFS200W and CWFS350W composites showed lower fatigue life compared with the $\mathrm{CWF}_{\mathrm{S}} 00$ composite. $\mathrm{CWF}_{\mathrm{S}} 00$ initially had longer particles compared with other pulverized $\mathrm{CWF}_{S}$. Hence, $\mathrm{CWF}_{\mathrm{S}} 00$ type composites showed higher crack propagation resistance properties (i.e., fatigue life) compared with the wet pulverized (smaller particle) $\mathrm{CWF}_{\mathrm{S}}$ composites. Fatigue test results of these materials indicated that only particle size was reduced by the wet pulverization of $\mathrm{CWF}_{\mathrm{S}}$, and that probably no significant fibrillation occurred on the particle surfaces. Consequently, crack arresting or deflection properties were not improved. Since the dry pulverization did not change the particle size of $\mathrm{CWF}_{S}$, as mentioned earlier, the dry pulverized $\mathrm{CWF}_{\mathrm{S}}$ composites showed similar fatigue performance to the $\mathrm{CWF}_{\mathrm{S}} 00$ composites. Considering the mill-plate gap in pulverization process, it was also noticed that the fatigue life of $C_{W} W_{S} 200 w$ was lower than that of $\mathrm{CWF}_{\mathrm{S}} 350 \mathrm{w}$ composite. This behavior also suggests that the wet pulverization of $\mathrm{CWF}_{\mathrm{S}}$ did not help to make fibrillation occur on the $\mathrm{CWF}_{\mathrm{S}}$ particle surfaces; wet pulverization probably promoted breaking of $\mathrm{CWF}_{\mathrm{S}}$ only.

Figure 7 shows $\mathrm{S}-\mathrm{N}$ curves of $\mathrm{CWF}_{\mathrm{L}}$ type composites. As shown in Figure 7, the wet pulverized $\mathrm{CWF}_{\mathrm{L}}$ composites exhibited higher fatigue life compared with that of initial and dry pulverized $\mathrm{CWF}_{\mathrm{L}}$ composites. In Figure 7, it can also be noticed that the dry pulverized $\mathrm{CWF}_{\mathrm{L}}$ composites showed the lowest fatigue performance. From the fatigue analysis of these materials, it was estimated that only the particle size of $C_{W} F_{L}$ was decreased by the dry pulverization of $C W F_{L}$. Hence, the dry pulverized $\mathrm{CWF}_{\mathrm{L}}$ composites exhibited the lowest fatigue performance. The highest fatigue performance of the wet pulverized $\mathrm{CWF}_{\mathrm{L}}$ composites was attributed to the higher aspect ratio, as well as the occurrence of fibrillation on the WF particle surfaces. It was assumed that the surfaces of WF particles were interconnected with other particles by the fibrils, thus, the fibrillated particle exhibited more crack arresting or deflection properties in $\mathrm{CWF}_{\mathrm{L}}$ composites.

When the fatigue performance of $\mathrm{CWF}_{\mathrm{L}}$ composite was evaluated in terms of mill-plate gaps, it was noticed that the fatigue life of $\mathrm{CWF}_{\mathrm{L}} 200 \mathrm{w}$ composite was higher compared with that of $\mathrm{CWF}_{\mathrm{L}} 350 \mathrm{w}$. This behavior was completely opposite that of $\mathrm{CWF}_{\mathrm{S}}$. Based on this analysis, it was assumed that the wet pulverization of $\mathrm{CWF}_{\mathrm{L}}$ not only reduced the particle size, but also assisted in causing fibrillation on the WF particle surfaces, which ensured more interfacial interaction between wood flour and PP matrix. Moreover, fatigue life of composites increased with increasing particle aspect ratio, as did tensile strength [41].Hence, the fatigue test results of $\mathrm{CWF}_{\mathrm{L}}$ composites indicated that the wet pulverization of WF increased the particle aspect ratio of wood flour. This result was in good agreement with the measured aspect ratio values of $\mathrm{CWF}_{\mathrm{L}}$. 

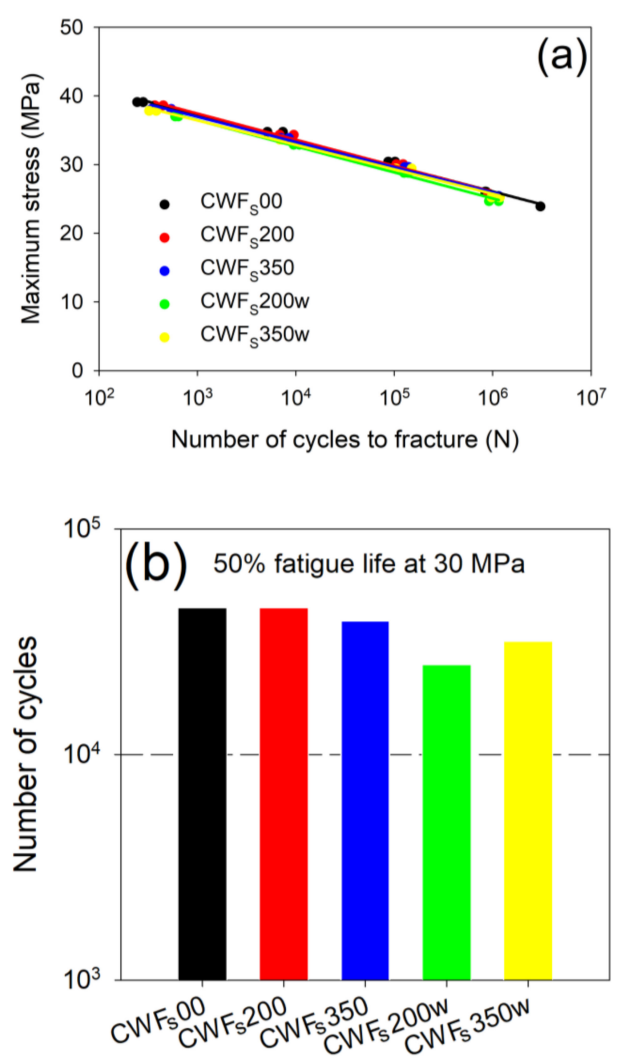

Figure 6. (a) $\mathrm{S}-\mathrm{N}$ curves and (b) half-fatigue life of $\mathrm{CWF}_{\mathrm{S}}$ type composites: $\mathrm{CWF}_{\mathrm{S}} 00, \mathrm{CWF}_{\mathrm{S}} 200$, $\mathrm{CWF}_{\mathrm{S}} 350, \mathrm{CWF}_{\mathrm{S}} 200 \mathrm{w}$, and $\mathrm{CWF}_{\mathrm{S}} 350 \mathrm{w}$.
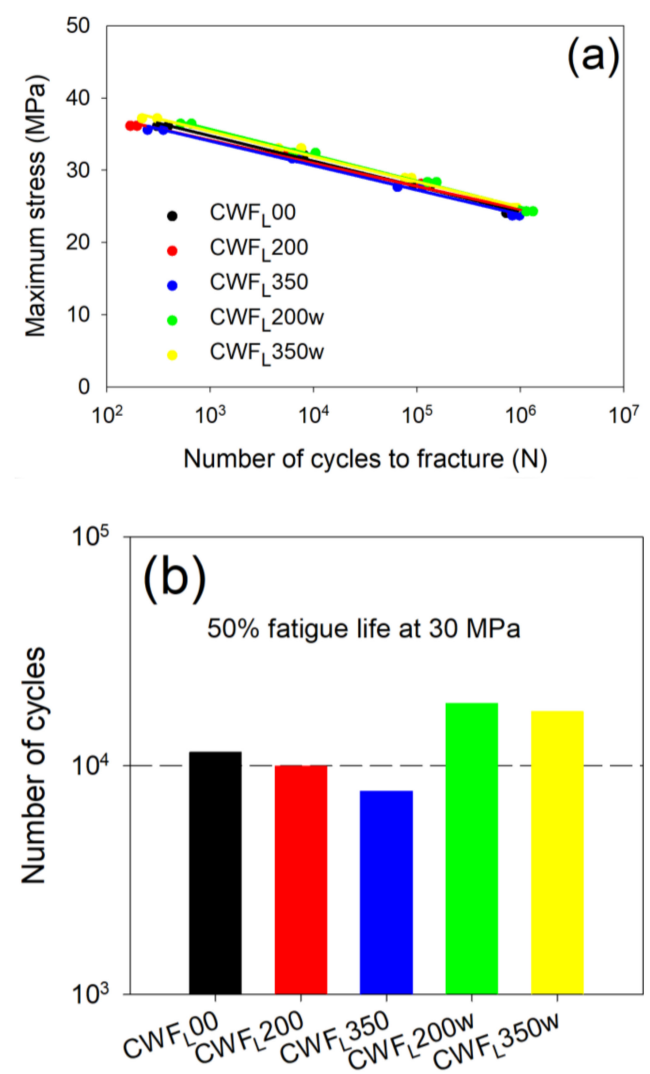

Figure 7. (a) S-N curves and (b) half-fatigue life of $\mathrm{CWF}_{\mathrm{L}}$ type composites: $\mathrm{CWF}_{\mathrm{L}} 00, \mathrm{CWF}_{\mathrm{L}} 200$, $\mathrm{CWF}_{\mathrm{L}} 350, \mathrm{CWF}_{\mathrm{L}}$ 200w, and $\mathrm{CWF}_{\mathrm{L}} 350 \mathrm{w}$. 
Figure 8 shows S-N curves of PWF type composites. In Figure 8, it can be noticed that, unlike CWF, both dry and wet pulverized PWF composites showed a higher fatigue performance than that of initial PWF composites. From the fatigue analysis of these materials, it was estimated that both dry and wet pulverization of PWF increased the particle aspect ratio. Hence, both dry and wet pulverized PWF composites exhibited improved fatigue performance. It was also noticed that PWF200 and PWF200W composites, pulverized at mill-plate gap $200 \mu \mathrm{m}$, showed the highest fatigue life.
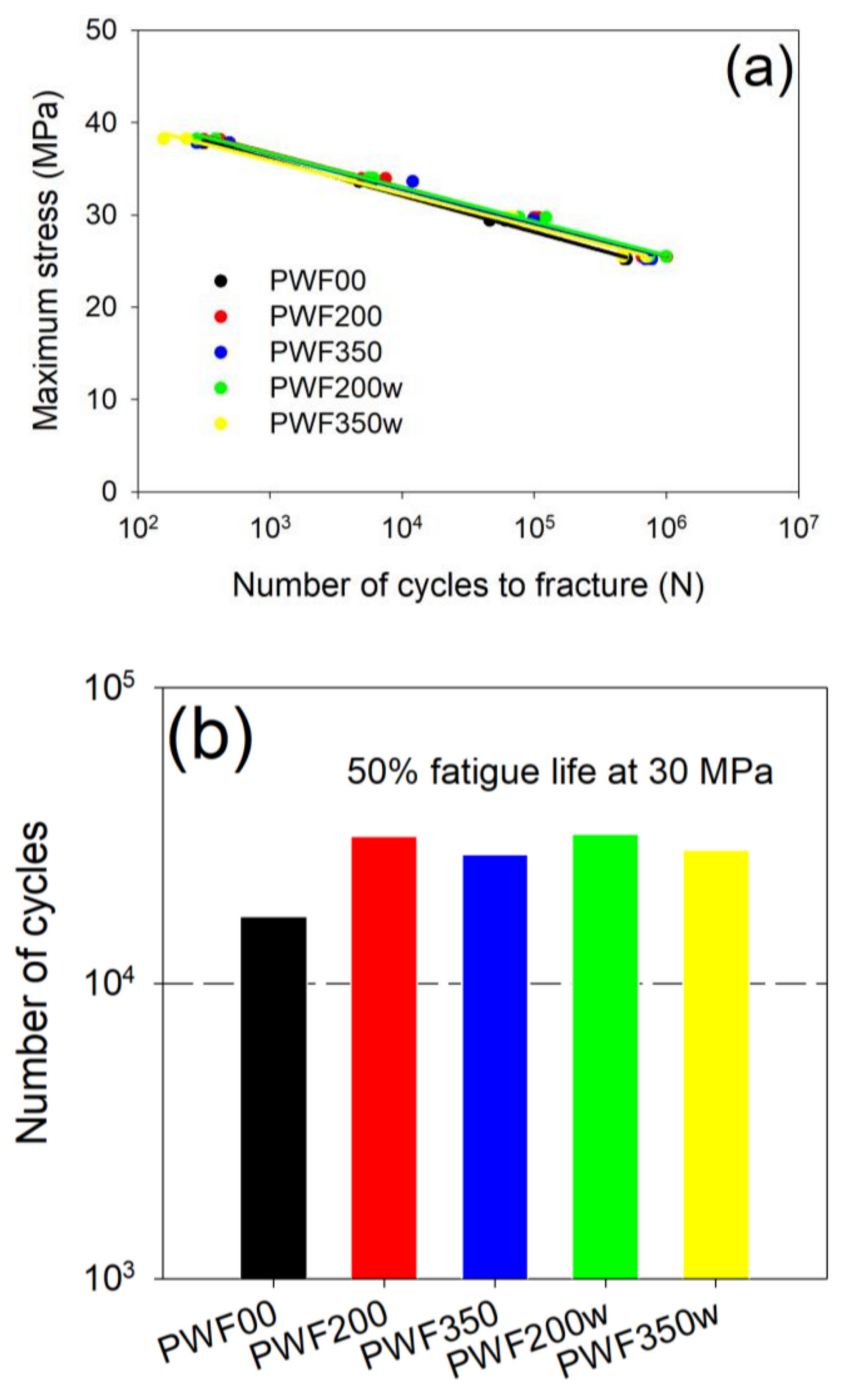

Figure 8. (a) S-N curves and (b) half-fatigue life of PWF type composites: PWF00, PWF200, PWF350, PWF200w, and PWF350w.

Figure 9 shows the optical microscopic images of the fatigue fractured specimens of polypropylene composites with different initial and wet pulverized wood flours at mill-plate gap $200 \mu \mathrm{m}$. The specimens were fractured at $60 \%$ of tensile strength load. The number of cycles to fracture is also shown on each image. Crack initiation of every specimen occurred from the end of the width direction, and the crack propagated across the width. In Figure 9, the upper part of the crack propagation is crack initiation. The crack deflecting or arresting character of wood flour particles is obvious in the crack propagation of each image. The crack propagations of wet pulverized WF composites were almost similar to the crack propagations of initial WF composites. However, if the crack propagations are deeply observed then it can be noticed that the crack propagation of the $\mathrm{CWF}_{\mathrm{S}} 00$ composite was more deflected than that of the $\mathrm{CWF}_{\mathrm{S}} 200 \mathrm{w}$ composite, i.e., wet pulverized short cypress flour had less capability to divert crack propagation. In the case of $\mathrm{CWF}_{\mathrm{L}}$ composites, the crack propagation of the 
$\mathrm{CWF}_{\mathrm{L}} 200 \mathrm{w}$ composite was more deflected than that of the $\mathrm{CWF}_{\mathrm{L}} 00$ composite, i.e., wet pulverized long-size cypress flour had more capability to arrest the crack than did the initial WF. The optical microscopic images of crack propagation of PWF00 and PWF200w composites also indicated that wet pulverized pine flour had higher crack arresting capability than the initial WF.
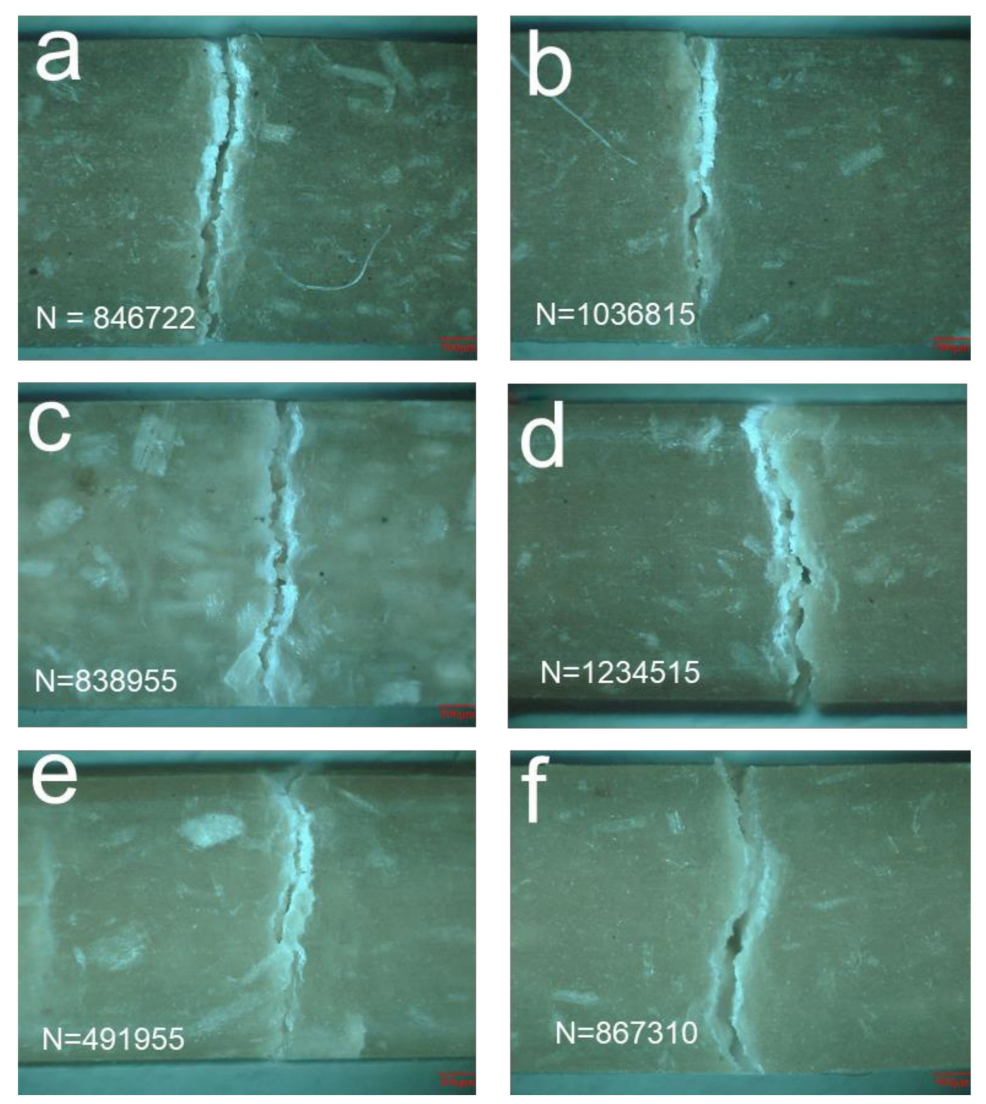

Figure 9. Optical microscopic images of fatigue fractured composites (a) $\mathrm{CWF}_{\mathrm{S}} 00$, (b) $\mathrm{CWF}_{\mathrm{S}} 200 \mathrm{w}$, (c) $\mathrm{CWF}_{\mathrm{L}} 00$, (d) $\mathrm{CWF}_{\mathrm{L}} 200 \mathrm{w}$, (e) PWF00, and (f) PWF200w. (N indicates number of cycles to fracture, and cyclic load was applied laterally on the images).

From fatigue test results, it can be concluded that the effectiveness of pulverization of wood flour on the fatigue performance of PP/WF composites solely depended on the initial wood flour particle characters. When WF particle aspect ratio increased and significant fibrillation on the particle surfaces occurred after pulverization, then the pulverized WF had a positive effect on the fatigue performance of PP/WF composites.

\section{Conclusions}

This study exclusively investigated the effects of pulverization of wood flour in both dry and wet conditions on the fatigue performances of polypropylene (PP)/wood flour (WF) composites. The effects of initial wood flour particle size, type of trees (namely cypress and scots pine trees) as well as mill-plate gap (200 and $350 \mu \mathrm{m}$ ) in pulverization were also evaluated.

The pulverization of wood flour affected the tensile strength values of composites. From the fatigue analysis of composites, it was found that the fatigue life of the wet pulverized short-size cypress flour filled polypropylene composites was not improved, i.e., pulverization of the short-size cypress wood flour had a negative effect on the fatigue life of PP/WF composite. In the case of long-size cypress wood four, the fatigue life of composites was increased. The wet pulverized long-size cypress flour filled polypropylene composites exhibited higher fatigue life compared with the initial and dry pulverized wood flour filled PP composites. Hence, the pulverization of long-size cypress flour had 
a positive effect on the fatigue life of PP/WF composites. The fatigue analyses of pine flour based composite also supported the positive effect of the pulverization of pine flour on the fatigue life of the composites. Thus, fatigue test results indicated that, depending on initial wood flour particles, an improvement of the fatigue life of PP/WF can be achieved by the wet pulverization of WF.

From the fatigue test results, it can also be concluded that the effectiveness of pulverization of wood flour on the fatigue performances of PP/WF composites depended on the initial wood flour particle characters. When the particle aspect ratio of WF increased and significant fibrillation on the particle surfaces occurred by pulverization then the pulverized WF exhibited a positive effect on the fatigue performance of wood composites. Thus, an improvement in fatigue life of PP/WF composite can be one step ahead by the wet pulverization of wood flour.

Author Contributions: Conceptualization, H.I. and S.O.; methodology, M.O., T.E., K.K. and H.N.; formal analysis, M.M.-U.H.; investigation, S.O., M.O., T.E., K.K. and H.N.; writing-original draft preparation, M.M.-U.H.; writing-review and editing, K.G.; supervision, K.G.

Acknowledgments: The authors would like to thank the Ministry of the Environment, Japan and Shizuoka University, Japan for financial support.

Conflicts of Interest: The authors declare no conflict of interest.

\section{References}

1. Danyadi, L.; Janecska, T.; Szabo, Z.; Nagy, G.; Moczo, J.; Pukanszky, B. Wood flour filled PP composites: Compatibilization and adhesion. Compos. Sci. Technol. 2007, 67, 2838-2846. [CrossRef]

2. Jacob, A. WPC industry focuses on performance and cost. Reinf. Plast. 2006, 50, 32-33. [CrossRef]

3. Bledzki, A.K.; Faruk, O.; Sperber, V.E. Cars from bio-fibres. Macromol. Mater. Eng. 2006, 291, 449-457. [CrossRef]

4. Clemons, C. Wood-plastic composites in the United States: The interfacing of two industries. For. Prod. J. 2002, 52, 10-20.

5. Arao, Y.; Nakamura, S.; Tomita, Y.; Takakuwa, K.; Umemura, T.; Tanaka, T. Improvement on fire retardancy of wood flour/polypropylene composites using various fire retardants. Polym. Degrad. Stab. 2014, 100, 79-85. [CrossRef]

6. Sun, L.; Wu, Q.; Xie, Y.; Song, K.; Lee, S.; Wang, Q. Thermal decomposition of fire-retarded wood flour/polypropylene composites. J. Therm. Anal. Calorim. 2016, 123, 309-318. [CrossRef]

7. Bakar, M.A.; Ishak, Z.M.; Taib, R.M.; Rozman, H.D.; Jani, S.M. Flammability and mechanical properties of wood flour-filled polypropylene composites. J. Appl. Polym. Sci. 2010, 116, 2714-2722. [CrossRef]

8. Mashkour, M.; Ranjbar, Y. Superparamagnetic $\mathrm{Fe}_{3} \mathrm{O}_{4} @$ wood flour/polypropylene nanocomposites: Physical and mechanical properties. Ind. Crops Prod. 2018, 111, 47-54. [CrossRef]

9. Luo, S.; Cao, J.; Sun, W. Evaluation of K raft lignin as natural compatibilizer in wood flour/polypropylene composites. Polym. Compos. 2017, 38, 2387-2394. [CrossRef]

10. Kiguchi, M.; Kataoka, Y.; Matsunaga, H.; Yamamoto, K.; Evans, P.D. Surface deterioration of wood-flour polypropylene composites by weathering trials. J. Wood Sci. 2007, 53, 234-238. [CrossRef]

11. Soccalingame, L.; Perrin, D.; Benezet, J.C.; Bergeret, A. Reprocessing of UV-weathered wood flour reinforced polypropylene composites: Study of a natural outdoor exposure. Polym. Degrad. Stab. 2016, 133, 389-398. [CrossRef]

12. Peng, Y.; Liu, R.; Cao, J. Characterization of surface chemistry and crystallization behavior of polypropylene composites reinforced with wood flour, cellulose, and lignin during accelerated weathering. Appl. Surf. Sci. 2015, 332, 253-259. [CrossRef]

13. Peng, Y.; Liu, R.; Cao, J.; Guo, X. Effects of vitamin E combined with antioxidants on wood flour/polypropylene composites during accelerated weathering. Holzforschung 2015, 69, 113-120. [CrossRef]

14. Ye, X.; Wang, H.; Wu, Z.; Zhou, H.; Tian, X. The functional features and interface design of wood/polypropylene composites based on microencapsulated wood particles via adopting in situ emulsion polymerization. Polym. Compos. 2018, 39, 427-436. [CrossRef] 
15. Malakani, M.; Bazyar, B.; Talaiepour, M.; Hemmasi, A.H.; Ghasemi, I. Effect of acetylation of wood flour and MAPP content during compounding on physical properties, decay resistance, contact angle, and morphology of polypropylene/wood flour composites. BioResources 2015, 10, 2113-2129. [CrossRef]

16. Askanian, H.; Verney, V.; Commereuc, S.; Guyonnet, R.; Massardier, V. Wood polypropylene composites prepared by thermally modified fibers at two extrusion speeds: Mechanical and viscoelastic properties. Holzforschung 2015, 69, 313-319. [CrossRef]

17. Luo, S.; Cao, J.; Peng, Y. Properties of glycerin-thermally modified wood flour/polypropylene composites. Polym. Compos. 2014, 35, 201-207. [CrossRef]

18. Zhu, L.; Cao, J.; Wang, Y.; Liu, R.; Zhao, G. Effect of MAPP on interfacial compatibility of wood flour/polypropylene composite evaluated with dielectric approach. Polym. Compos. 2014, 35, 489-494. [CrossRef]

19. Danyadi, L.; Moczo, J.; Pukanszky, B. Effect of various surface modifications of wood flour on the properties of PP/wood composites. Compos. Part A 2010, 41, 199-206. [CrossRef]

20. Kim, H.S.; Lee, B.H.; Choi, S.W.; Kim, S.; Kim, H.J. The effect of types of maleic anhydride-grafted polypropylene (MAPP) on the interfacial adhesion properties of bio-flour-filled polypropylene composites. Compos. Part A 2007, 38, 1473-1482. [CrossRef]

21. Carlborn, K.; Matuana, L.M. Influence of processing conditions and material compositions on the performance of formaldehyde-free wood-based composites. Polym. Compos. 2006, 27, 599-607. [CrossRef]

22. Hristov, V.N.; Vasileva, S.T.; Krumova, M.; Lach, R.; Michler, G.H. Deformation mechanisms and mechanical properties of modified polypropylene/wood fiber composites. Polym. Compos. 2004, 25, 521-526. [CrossRef]

23. Lee, S.Y.; Yang, H.S.; Kim, H.J.; Jeong, C.S.; Lim, B.S.; Lee, J.N. Creep behavior and manufacturing parameters of wood flour filled polypropylene composites. Compos. Struct. 2004, 65, 459-469. [CrossRef]

24. Ichazo, M.N.; Albano, C.; Gonzalez, J.; Perera, R.; Candal, A.M. Polypropylene/wood flour composites: Treatments and properties. Compos. Struct. 2001, 54, 207-214. [CrossRef]

25. Oksman, K.; Clemons, C. Mechanical properties and morphology of impact modified polypropylene-wood flour composites. J. Appl. Polym. Sci. 1998, 67, 1503-1513. [CrossRef]

26. Myers, G.E.; Chahyadi, I.S.; Coberly, C.A.; Ermer, D.S. Wood flour/polypropylene composites: Influence of maleated polypropylene and process and composition variables on mechanical properties. Int. J. Polym. Mater. 1991, 15, 21-44. [CrossRef]

27. Kokta, B.V.; Raj, R.G.; Daneault, C. Use of wood flour as filler in polypropylene: Studies on mechanical properties. Polym.-Plast. Technol. Eng. 1989, 28, 247-259. [CrossRef]

28. Stark, N.M.; Rowlands, R.E. Effects of wood fiber characteristics on mechanical properties of wood/polypropylene composites. Wood Fiber Sci. 2003, 35, 167-174.

29. Zaini, M.J.; Fuad, M.A.; Ismail, Z.; Mansor, M.S.; Mustafah, J. The effect of filler content and size on the mechanical properties of polypropylene/oil palm wood flour composites. Polym. Int. 1996, 40, 51-55. [CrossRef]

30. Maiti, S.N.; Hassan, M.R. Melt rheological properties of polypropylene-wood flour composites. J. Appl. Polym. Sci. 1989, 37, 2019-2032. [CrossRef]

31. Inoue, T.; Suzuki, T. Selective crosslinking reaction in polymer blends. III. The effects of the crosslinking of dispersed EPDM particles on the impact behavior of PP/EPDM blends. J. Appl. Polym. Sci. 1995, 56, 1113-1125. [CrossRef]

32. Niu, Z.; Chen, Y.; Feng, J. Preparation, structure, and property of wood flour incorporated polypropylene composites prepared by a solid-state mechanochemical method. J. Appl. Polym. Sci. 2016, 133, 43108. [CrossRef]

33. Makise, R.; Okamoto, M.; Hasegawa, T.; Ito, H.; Minamino, J.; Isa, A.; Kojima, Y. Effect of the shape of pulverized wood flour on the mechanical properties of wood-plastic composites. In Proceedings of the 11th Pacific Rim Bio-Based Composites Symposium (BIOCOMP 2012), Shizuoka, Japan, 27-30 November 2012; pp. 461-466.

34. Haque, M.M.; Goda, K.; Ito, H.; Ogoe, S.; Okamoto, M.; Ema, T.; Kagawa, K.; Nogami, H. Melt-viscosity and mechanical behaviour of polypropylene (PP)/wood flour composites: Effect of pulverization of wood flour with and without water. Adv. Ind. Eng. Polym. 2018. [CrossRef] 
35. Isa, A.; Toyoda, T.; Suzuki, S.; Kojima, Y.; Ito, H.; Makise, R.; Okamoto, M. The effects of wet-milled wood flour on the mechanical properties of wood flour/polypropylene composites. J. Wood Chem. Technol. 2014, 34, 20-30. [CrossRef]

36. Kanters, M.J.W. Prediction of Long-Term Performance of Load-Bearing Thermoplastics. Ph.D. Thesis, Eindhoven University of Technology, Eindhoven, The Netherlands, 3 September 2015.

37. Yang, H.S.; Qiao, P.; Wolcott, M.P. Fatigue characterization and reliability analysis of wood flour filled polypropylene composites. Polym. Compos. 2010, 31, 553-560. [CrossRef]

38. Gaurav, A.; Singh, K.K. Fatigue behavior of FRP composites and CNT-Embedded FRP composites: A review. Polym. Compos. 2018, 39, 1785-1808. [CrossRef]

39. Reifsnider, K. Fatigue behavior of composite materials. Int. J. Fract. 1980, 16, 563-583. [CrossRef]

40. Nordin, M.N.A.; Makino, Y.; Goda, K.; Ito, H. Fatigue properties of wood plastic composites. Sen'i Gakkaishi 2015, 71, 339-344. (In Japanese)

41. Lavengood, R.E.; Gulbransen, L.B. The effect of aspect ratio on the fatigue life of short boron fiber reinforced composites. Polym. Eng. Sci. 1969, 9, 365-369. [CrossRef]

(C) 2019 by the authors. Licensee MDPI, Basel, Switzerland. This article is an open access article distributed under the terms and conditions of the Creative Commons Attribution (CC BY) license (http:/ / creativecommons.org/licenses/by/4.0/). 